Journal of Social and Development Sciences

Vol. 4, No. 9, pp. 412-424, Sep 2013 (ISSN 2221-1152)

\title{
The Duality of Jatio Sangsad Bhaban and the Notion of Nationalism
}

\author{
*Bayezid Ismail Choudhury, Peter Armstrong \\ University of Sydney, Australia \\ *bcho0140@usyd.edu.au
}

\begin{abstract}
Jatio Sangsad Bhaban or Nation Assembly Building or Capitol Complex of Bangladesh, is an iconic building designed by American architect Louis. I. Kahn. It is regarded as the national emblem and the national identity of Bangladesh. It has assumed a symbolic role in the nationalist movement of the Bangladeshi people which lead to the emergence of independent Bangladesh. Drawing on Peter Alter's theory of nationalism, this paper will argue that his construct of the dual positive and negative character of nationalism aptly fits the role the Jatio Sangsad Bhaban has played from its outset, representing as his four aspects of nationalism: oppression, and at the same time emancipation, the repository of danger, and opportunity.
\end{abstract}

Keywords: Nationalism, Jatio Sangsad Bhaban, Duality, Bangladesh, Louis I Kahn

\section{Introduction}

Jatio Sangsad Bhaban (JSB), or the National Assembly Building in Dhaka, Bangladesh, is a landmark in modern world architecture. It was commissioned in 1962 and designed by master architect Louis I. Kahn ${ }^{1}$. The Capitol Complex, with its picturesque surroundings on almost 1000 acres, has taken on a deep significance not only for its architectural merit but also as a symbolic edifice with a multifaceted character and disposition ${ }^{2}$. After passing through a long history of drama and paradox (Choudhury \& Armstrong, 2012) it has become a national emblem of the identity of democratic Bangladesh ${ }^{3}$. The JSB is ostensibly a product of nationalism. It was commissioned by the military dictator of West Pakistan, Ayub Khan, in 1962 in response to the nationalist movement of the East Pakistanis in the 1950s. The East Pakistani people had held inherent grievances from the very origin of Pakistan as an independent nation, comprising East and West Pakistan, in 1947 (Mascarenhas, 1971; Uddin, 2006). The emancipation Pakistan achieved was not the one that had been envisaged in their hearts and minds (Baxter, 1997). ${ }^{4}$. As Baxter states, "but to the majority of East Pakistanis this would not prove to be the independence they desired" (Baxter, 1997). West Pakistan subjugated East Pakistan in all aspects of life including economy, culture, foreign policy, participation in public service and defence (Lambert, 1959). In this political environment Ayub Khan envisaged that commissioning the National Assembly building in Dhaka would appease the people of East Pakistan and be instrumental in gaining their support (Ksiazek, 1995). Thus the JSB came into being as a response to the nationalist movement of East

1 The Capital Complex was designed by Master Architect Louis I. Kahn, who. Continued working on the project till his death in 1974.It was completed in 1983 after twenty-one years, the same time occupied by the construction of the Taj Mahal. Once situated on the periphery of Dhaka, it is now at its centre, due to the city's rapid growth (Choudhury \& Armstrong, 2012).

${ }^{2}$ There persists a misconception about the actual area of JSB. According to a document archived in the Public Works department an area of 1000 acres was initially planned Subsequently, however, only 610 acres were allocated to the building (File No- W.C.P-58/ace, Collection No-1, Year- 1964-65).

${ }^{3}$ Bangladesh (Formerly East Pakistan) earned its independence from Pakistan in 1971. In 1947 when the British quit the Indian sub-continent they divided India into three parts, comprised of West Pakistan, India and East Pakistan, based mainly on the religious affiliations of the respective populations.The area where Muslims were in the majority became Pakistan (East and West) and the rest became India.

${ }^{4}$ According to Schendel (2009), the underprivileged and downtrodden Muslims in Bengal had desperately sought emancipation from their Hindu landlords. Therefore they vehemently supported the cause of independent Pakistan and felt betrayed after liberation because of their subordination to West Pakistan. 
Pakistan. However Ayub Khan had misread the pulse of the people of Bengal and his tactic failed to appease them. Far from placating the Bengalis the National Assembly Building paradoxically became to them a symbol of an autocratic regime (Schendel, 2009; Choudhury \& Bell, 2011).

What had once been a spectacular manifestation of elitism evolved into one of nationalism after East Pakistan achieved independence in 1971. When Bangladesh emerged as independent country the National Assembly Building, still under construction, took on a new identity. Almost overnight it was transformed into a symbol of the aspirations of the people of Bangladesh, one reinforced by a new agreement between the American consultant and sovereign Bangladesh ${ }^{5}$. In the historical process of independence the JSB had changed from a symbol of the old establishment to an emblem of a new nationalism. Vale claims that "Grand symbolic state buildings need to be understood in terms of the political and cultural contexts that helped to bring them into being (Vale, 2008, p.3) .The terms nationalism ${ }^{6}$, which is a political and cultural product, can be linked symbolically to the JSB. Guibernau argues that"The power of nationalism emanates from its ability to engender sentiments of belonging to a particular community. Symbols and rituals play a major role in the cultivation of a sense of solidarity among the members of the group" (Guibernau, 2007, p.3). The JSB, which is now regarded as a symbol of national identity (Vale, 2008) plays a vital role in shaping the nationalist zeal of the Bengali people. Nationalism is a political and cultural construct of human nature (Kamenka, 1973).Like the duality of human nature ${ }^{7}$, the inherent philosophy of nationalism revolves around its dual character. The duality of nationalism is explicit in the writing of many eastern and western scholars, who will be discussed later (Eriksen, 1991). A discussion of duality as the fundamental theme of Bangladeshi nationalism is central to this paper, a duality reflected by the unfolding narrative, in line with Peter Alter's ${ }^{8}$ theory of nationalism, of the dual character of that product of nationalism, the JSB. Alter argues, "It is clear that nationalism, so convenient a label and justification for many developments, conceals within itself extreme opposites and contradictions. It can mean emancipation, and it can mean oppression: nationalism, it seems is a repository of dangers as well as opportunities" (Alter, 1994, p.2,).

The paper thus articulates that the iconic JSB which emerged as a response to the nationalist movement is seemingly a nationalist product. The duality of this nationalist product is expressed as a positive and negative notion of nationalism through its physical (iconic masterpiece) and subjective (its history of birth, pro-people and anti people constitutional issue etc.) form. Up until now, this iconic masterpiece has been perceived as an architectural masterpiece of famous architect Louis I Kahn. Thus only its objective meaning has been unravelled. This paper attempts to unfold its subjective meaning through Peter Alters' dual notion of nationalism. The subjective meaning derived from its history of inception and other issues pertaining to its legislative function, is considered to add value to its status of iconic architecture. By analysing such non

5 The first memorandum of agreement between the Government of Pakistan and Louis I. Kahn was signed on January 9,,1964.(file no W-CAP-58/ACE, Collection no -3 year 1966, Public Works Department, Bangladesh) and the second at the end of 1973.(File No-W-CAP-16(1) ACE, Collection No-X1 Year-1973-74, Public Works Department, Bangladesh)

${ }^{6}$ Nationalism is an ideology, a feeling of belonging to a similar ethnic group, race, culture, geography and political belief (Beiner, 1999).The paper presents an elaborate discussion on nationalism and the duality of nationalism.

7 It has been argued that duality is intrinsic to human nature. Duality persists in the body and soul in the personal and impersonal dispositions (Durkheim, 2005). It can be expressed through the opposing traits of 'angel and beast', our 'grandeur' and our 'wretchedness', or moral and immoral behaviour (Durkheim, 2005). Hobbes argues the duality of humans is manifest in the notions of 'reason' and 'passion' (Miller, 1993).Physiologically the human brain is divided into two parts, the subcortex (components of the limbic system) and the neocortex (components of intellectual functions.) These are positioned as the left and right hemispheres of the human brain (Miller, 1993)

${ }^{8}$ Peter Alter is a Professor of Modern History at the University of Cologne. He is an expert in the discourse of nationalism and best known for his book, Nationalism. 
physical attributes of this building, the paper elevates the status of JSB from a mere building to architecture. As Hershbergar states 'Meaning is therefore, a necessary part of what makes building architecture' (Hershberger, 1970, p.39). The paper has five parts. The introduction will be followed by discussions of the premise of nationalism, the duality of nationalism and the duality of Bangladeshi nationalism. The fifth part will reveal the duality of the JSB in line with four different aspects of Peter Alter's theory. The paper concludes with a retrospect of its argument.

\section{The Premise of Nationalism and Bangladeshi Nationalism}

Anderson argues," Nation, Nationality, and Nationalism - all have proved notoriously difficult to define, let alone to analyze", (Anderson, 2006, p.3). Alter argues that academics are still grappling with an appropriate definition of 'nationalism', 'nationality' and 'national identity'. However an attempt has been made in this paper to understand the JSB, which was initially used by the political establishment to appease the breakaway nationalist movement and paradoxically became over time a symbol of that same impetus toward nationalism. Therefore right from the outset of the paper the issue of nationalism calls for lucid discussion. The earliest mention of nationalism is found in the work of the German philosopher Johann Gottfried Herder in 1774 (Alter, 1994). Nationalism is inherently a state of mind, a collective cultural identity constituted and constructed through memory, fantasy, whim, narrative and myth (Kramer, 1998). It is a system of thought that inculcates hopes, aspirations, emotions, passion, aggression and action. It is a vehicle for achieving a common goal for a like-minded group of people. Language, culture, historical consciousness, mores, social communication, religion and political goals are important components of nationalism (Alter, 1994). Ericksen argues that "Nationalism entails the ideological justification of a state, actual or potential"1 (Eriksen, 1991, p. 265 ,). The three tenets of nationalism are autonomy, unity and identity. The concept of nationalism was popularized through the work of Western scholars (Hutchinson, 1994). Religion and language are the two entities most powerfully linked to nationalism in its discourse (Kramer, 1998): both factors were pivotal in shaping the character of Bangladeshi nationalism. In summary, nationalism is an ongoing process, a derivative of sentiment or identity, an expression of political and cultural rhetoric, an ideology, a range of principles, and a conceptualisation of a social-political movement (Beiner, 1999).

Nationalism is the most pressing issue in contemporary world politics (Lowrie, 1930). At present there exist some seventy distinct national states in the world. Thirty-five of these are in Europe. The largest national state in Europe is (Lowrie, 1930). The debate over the emergence of nationalism as a relatively modern construct is wide-ranging (Beiner,1999).Although most Marxists interpret it as modern phenomenon related to the development of capitalism the impact of nationalism as an ideology and movement can be seen in the relatively recent American and French revolutions (Smith, 2006). Gellner, a scholar on nationalism, views it as an outcome of the development of industrial society which was already evident in parts of Europe at the end of the thirteenth century, and emerged in the nineteenth and twentieth centuries throughout most of the world (Kellas, 1998). In most cases the nationalist movement is manufactured among elites and gradually finds its way to the working class (Hutchinson, 1994). For example, the Japanese and German nationalist movements were "top down" ones (Hutchinson, 1994). Any nationalist movement encounters either suppression (in an authoritarian state) or free expression (in a democratic state) depending on the structure of state (Kellas, 1998). There are three different kind of nationalism. The first is ethnic nationalism, which denotes a common ethnic descent among groups, such as Kurds, Latvians and Tamils. The people of Bangladesh belong to this category. A second, more liberal, form of nationalism, which hinges on a shared national culture independent of ethnic descent, is known as 'social nationalism'. In this category anyone can become member of a nationalist group irrespective of different ethnicities. For example Scots, Ukrainians and Catalans are composed of ethnically diverse peoples. The third category is official nationalism, which is based on patriotism, with no relationship to ethnic or cultural criteria. This kind of nationalism embraces all those legally entitled to be citizens, irrespective of their creed, religion, ethnicity, national identity and culture: for example the UK, the USA and Australia (Kellas, 1998).

Nationalism was a transformative movement that emerged in the nineteenth century (Kellas, 1998).Through the unification movement the core state (e.g., the kingdoms of Prussia in Germany and Sardinia in Italy) engulfed and subverted neighboring states, making them dysfunctional. This type of nationalism is also called 'Risorgimento' nationalism (Kellas, 1998). On the other hand, national secession movements caused existing 
states to disintegrate. This was evident in the nationalist movements in Ireland, Greece, Poland and Serbia, which achieved independence respectively from Britain, the Ottoman Empire, the Russian Empire and the Austrian Empire (Kellas, 1998). Kelles also identified four other kinds of nationalism. The first is reform nationalism, in which nationalist movements are instigated by a ruling class, not by an anti-establishment group. Examples of these are Japan in the mid-nineteenth century and Turkey in the early twentieth. The second type is integral nationalism, which expresses itself through totalitarian movements such as Fascism and Nazism and proclaims its superiority over all other forms of government. Examples are Mussolini's Italy, Hitler's Germany and Franco's Spain (Kellas, 1998).The third is colonial nationalism, a nationalist movement initiated by European settlers in the European colonial empires (especially those of the British, Spanish, Portuguese, Dutch and French). This brand of nationalism paved the way for the independence of colonies from their mother countries. The American Revolution is a good example of this kind of nationalism. The British colonies in North America received their independence in 1776, followed by the Spanish and Portuguese in Latin America in the early nineteenth century. Finally there is anti-colonial nationalism, which emerged out of indigenous 'national liberation' and 'anti colonial movements' in the European colonial empires in a way similar to the nationalist movement in Europe ( Kellas, 1998).The emergence of Bangladesh is an example of such an anti-colonial movement away from British, and subsequently Pakistani, rule.

The responses of peoples to nationalist movements take two forms: the political, which is 'rational', and the cultural, which is 'mystical' (Kohn, 2008). Political nationalism appeared first in the West: England, France, the Netherlands, Switzerland, the USA and the UK). When nationalism emerged in the West it aimed to transform the existing 'top down' state into a people's state. Nationalistic movements helped shape institutional and constitutional forms of government. Sophisticated urban middle classes gave nationalism an institutional form (Hutchinson, 1994). The response to cultural nationalism movements in the East was different, as an enlightened middle class did not exist there. Driven by predominantly agrarian and peasant classes the notion of nationalism in the East was generated by communities' attitudes to myth shared historical memories and unique cultural attributes. In cultural nationalism people have an interest in adhering to their culture and preserving it. The response to institutional frameworks here was slower than in the West, and imitative of it (Kohn cited in, Hutchinson, 1994). The nationalist movement in Bangladesh for the most part falls into this category. The first of such cultural nationalism is the important work by Benedict Anderson.

There are three viewpoints from which nationalism is seen as a negative phenomenon. The first of these claims that it provides a narrow perspective, a one-sided view. The second points to the division nationalism causes between 'us' and 'them.' The third, the Marxist view, claims that it relies upon religious feelings to fabricate ideas (Özk* ${ }^{*} \mathrm{ml}^{*}, 2000$ ). These antagonistic views are refuted by the two most important contemporary analysts of nationalism, Anthony Smith and Benedict Anderson, who offer arguments that support nationalism. The former points favourably to the continuity with the past afforded by nationalism, and the latter propound the imaginative and socio-cultural appeal of the construct of state. As the leading proponent of nationalism, Anderson's focus is its psychological appeal (Kellas, 1998). His concept of 'imagined communities', encompassing cultural nationalism, generated an enthusiastic response in the eastern world. Anderson visualizes a nation as a 'distinctive modern construction' evolved from closely knit psychic associations, having imaginative ties, without an actual physical association, spread across the globe. The idea of 'imagined communities' unites segregated and dispersed populations in a shared identity. Thus the formation of a nation is an imaginative and symbolic process. This idea of the imagined community has provided the impetus for many explorations of the idea of the thematic structure of nationalism (Kramer, 1998).

Snyder divides nationalism into geographical categories: "Europe-Fissiparous Nationalism", Africa-black nationalism", "Middle East politico-religious nationalism", "Asia-anticolonial nationalism", "Latin Americapopulist nationalism", "United States-melting pot nationalism" and "Soviet Union-messianic nationalism( Özk*r*ml*, 2000).The 'dark side' of nationalism has been revealed in the rapid rise of ultra-nationalism, neonationalism, and anti-Semitism in both western and eastern European states (Hutchinson, 1994). Nationalism can have an extremely powerful and detrimental impact. It engenders the breakdown of traditional values and the emergence of a restless, secular and educated generation striving for power (Hutchinson, 1994). The whole subject of nations and nationalism is wide and diverse. Its multiplicity of notions and themes has made 
it a diverse discipline combining anthropology, political science, sociology, social psychology, linguistics, international relations, geography, philosophy and international law (Hutchinson, 1994).

This paper sets out to explore the notion of nationalism through a symbolic building in the context of the third world. Third world nationalist movements are fundamentally different from those of the developed West. They came into being in an arena where the colonial ruler and the indigenous ruled had different notions of the nationalistic idea (Alter, 1994). Nationalism became a forceful power in the post-war epoch in the former colonies of Asia and Africa. The withdrawal of European colonial rule gave the impetus to national independence movements in the newly independent countries (Alter, 1994). With regard to third world nationalism in former European colonies, Sathyamurty argues that "Autonomy and independence have also been viewed in much more radical terms by national liberation movements which shape their struggles in such a way as to combine the aim of eradicating colonialism and imperialism with the goal of restructuring the society" (Alter,1994). In the case of Bangladesh the notion of national emancipation remained remote even after liberation from British rule. The nationalist force of Bangladesh waged another war to achieve the desired goal of eradicating colonialism. After the partition of India and Pakistan in 1947 the decade of the fifties was one of tumult as the Bengali nationalist movement was forged. Schendel asserts this mid 50 was a brief period of Bengali renaissance against colonial occupation the 1952 vasha andolon, or 'language movement', was the forerunner of all subsequent movements, such as the six-point demand in 1966 which called for greater autonomy for the East Pakistani people (Schendel, 2009). Schendel claims that the six-point demand heralded the independence of Bangladesh. After the refusal of the West Pakistani government to hand over power to the East Pakistani political party after the 1970 elections of the East Pakistanis declared a war of independence on March 26, 1971 (Schendel,2009). After a nine-month struggle East Pakistan emerged as the independent nation of Bangladesh on December 16, 1971. The JSB emerged as the new symbol of that struggle in the period following British colonial rule (Schendel, 2009).

Duality of Nationalism: That nationalism has a dual character is widely accepted. Apart from featuring in the work of Alter and other western scholars the idea of the duality of nationalism is also evident in the writings of renowned eastern scholars like Sathyamurthy (1983), Tagore (1991), Nazrul Islam (Mitra, 2007) and Osmany (1992). The Nobel laureate Tagore postulated the duality of Japanese nationalism, claiming that the Japanese imitated western ideas while drawing on their own deeply ingrained cultural roots (Tagore, 1991). He discerned this duality in Indian nationalism too, arguing "When our nationalists talk about ideals them [political leaders] forget that the basis of nationalism is wanting. The very people who are upholding these ideals are themselves the most conservative in their social practice" (Tagore, 1991, p. 94). The national poet of Bangladesh, Nazrul Islam, also perceived this duality in the liberating ideologies of Hindus and Muslims visà-vis in the orthodoxy of their thought (Mitra, 2007). The subject of this paper, the JSB, appears to have changed in its function from an entity suppressing nationalistic aspirations in the pre-independence period to an emblem for the East Bengali people in the post-independence period; a process accurately reflecting the dual character of nationalism, which is the essence of this paper. Nationalism is perceived geopolitically as a complex dual force. On the one hand it can be "aggressive and a tool of expansionism", and on the other it can appear as a "truly peace-keeping and culturally integrating force" within a nation's geography (Eriksen, 1991). Erickson further characterized the duality of nationalism in arguing that while it is associated wirth humanity and emancipation from human bondage it is conversely subversive of citizens' rights and denies the basic right of membership of a community (1991). He states, "Depending on the social context, then, nationalism may have socio-culturally integrating as well as disintegrating effects ${ }^{1}$ (Eriksen, 1991, p.266,)."

The duality and diversity of nationalism varies with the geographical disposition of people. The 'western' type of nationalism is regarded as ethnically 'inclusive', highlighting the cultural homogeneity of states that incorporate multiple ethnic groups. In this kind of nationalism all citizens within the boundary of a given nation are valued as members of the 'nation-state'. 'Eastern' nationalism, on the other hand, is regarded as 'ethnically exclusive' based on the notion of common descent and culture. Under the aegis of this nationalism only selected members with the same ethnic origin have the right to be members of the 'nation-state'. As well as many Asian countries some eastern European countries fall into this category (Kellas, 1998). Kellas delineated this duality in this way: " the inclusive nationalism is more liberal and democratic, and do not engage in genocide, transfers of population etc. The exclusive nationalism is intolerant and often lead to authoritarianism. Examples of the former are Irish, Scottish, Catalan and Norweigian nationalisms, and of the 
latter, Bulgarian, Turkish, Serb, Tamil and Sikh nationalism' (Kellas, 1998, p 91). In Ozkirimli's view of the dual notion of nationalism, the western version is expressed through public agreement and consensus while the non-western one is governed by an irrational and authoritarian approach (Özk* $\left.\mathrm{r}^{*} \mathrm{ml}^{*}, 2000\right)$. Social structure also mediates the dual nature of nationalism. The two prongs of nationalism tend to be a proletariat and an intelligentsia (Gellner, 1998). Both classes contributed to the emergence of both the notion of nationalism-imperialism and that of anti-imperialism. Both strove by means of nationalist movements for political, social, economic and cultural emancipation (Alter, 1994).

Sathamurti argues, "While in one sense 'nationalism' appears at this stage as an anti-imperialist ideology, in another sense it provides the opportunity for the nascent national bourgeoisie to embark upon a process of accumulation of capital in the indigenous society" (Sathyamurthy,1983, p.6,). In this perspective nationalism inherently has a dual nature. The history of Bangladesh aptly reflects Sattaymurthy's theory. The Awame League, which is regarded as the nationalist force that led Bangladesh's war of independence, ironically became involved in accumulating wealth and power after independence had been achieved (Baxter, 1997).. That is, the leaders of the nationalist force who inspired the nation and pushed it into a bloody freedom fight capitalised on the power of the newly independent government in order to plunder wealth, power and dignity from the mass of the people (Baxter, 1997). Finally, the duality of nationalism can be summarized clearly by Kramer's statement that "Nationalism are given their historical meaning through oppositions such as western/eastern, political/cultural, old/new, liberal/conservative, and civic/ethnic. These oppositional categories help historians compare and identify various phases of nationalism, but they also tend to convey a strong ethical distinction between good and bad" (Kramer, 1998, p.14),

Duality of Bangladeshi Nationalism: The duality of nationalism identified by these scholars is also evident in Bangladeshi nationalism. Indeed, at present, two opposite streams of Bangladeshi nationalism are the hall mark of 'Bangladeshi nationalism'. Madan terms these two different faces the ethno-religious and religiousethnic aspects of Bengali nationalism. They refer respectively to "Bengali-Muslim (non -secular) and MuslimBengali (secular) identity" (Madan, 1972).The Muslim-Bengali or secular identity of Bangladeshi nationalism evolved in the $13^{\text {th }}$ century. At present these two streams of nationalism are harbored under the two mainstream parties, namely Awame League and Bangladesh Nationalist Force. The notion of Bengali nationalism came into existence after the initiation of the Awame League's six-point program in 1965 (Schendel, 2009). A new concept of Bangladeshi nationalism developed by Ziaur Rahman as an alternative means of expressing peoples' aspiration came into being after 1977 as opposed to the existing version of Bengali nationalism. The Muslim identity rooted in the Bengali people in the 13th century was pivotal in shaping the new narrative, which occurred when the down trodden Hindu community embraced Islam as a means of emancipation (Schendel, 2009).This Bangladeshi, or Muslim Bengali, nationalism is a recreation of Bhashani's National Awame Muslim League of 1949 which came into being prior to the development of Sheikh Mujib's creation of Bengali nationalism..

To materialize his notion of Bangladeshi nationalism, Ziaur Rahman inclined to Islamic strictures and inserted a clause "faith in the almighty Allah" as a fundamental principle of the constitution in 1977 (Khan, 1985). After Rahman's death in 1981, his wife Khaleda Zia fostered this perception of Bangladeshi nationalism. However Sheikh Hasina, the present Prime Minister and daughter of Shjeikh Mujib, carries the torch of a secular version of nationalism ${ }^{9}$ (Schendel, 2009). Schendel argues in this regard, "It is through these two women that a crucial set of unresolved tensions in Bangladesh's political system has taken shape. This is the wrangle over the identity of the nation and the correct national ideology. It gave a new twist to the long history of dual Bengali -Islamic identities in the Bengal delta" (Schendel, 2009, p. 201).

\section{JSB: An Emblem of Duality of Nationalism}

The abstruse and complex dual character of nationalism and Bangladeshi nationalism in particular, can be illuminated through an anatomical dissection of the JSB's physical and intangible attributes. The dual

${ }^{9}$ The slogan of the non-secular Nationalist Party Bangladesh Jindaba ('Long Live Bangladesh') contains an Islamic word, while that of the secular version of nationalism, Joy Bangla('Victory of Bangladesh') is composed of words of entirely Sanskrit origin (Schendel, 2009) 
characteristics of the JSB have been scanned here through the lens of Alter's theory of the duality of nationalism. Alter posits four different components that signify the duality of nationalism: oppression, emancipation, repository of danger, and opportunity. Although there is a fine line between the ideas of oppression and that of danger and between those of emancipation and opportunity, we have tried to provide the different connotations of those meanings. Oppression has been analysed in the purview of political issues instrumental to the birth of JSB, and the issues of emancipation and danger revolve around constitutional issues raised under the auspices of JSB ${ }^{10}$. The scope of opportunity has been attributed to the architectonics of this world class masterpiece and its promise as an outstanding democratic institution.

JSB: An Emblem of Oppression: The very origin of Jatio Sangsad Bhaban had an oppressive and ominous disposition. When Pakistan seceded from British India in August 1947 it emerged with inherent disagreements and grievances (Mascarenhas, 1971). The two parts of Pakistan, East and West, were segregated in every aspect of life apart from geography. The differences were especially noticeable in cuisine, clothing, customs and rituals, apart from religion (Schuman, 1972) .The Bangladeshis' grievances against West Pakistan were based on four major issues: exclusion from participation in decision making-processes; the failure to recognize Bangla as the national language of East Bangladesh; the denigration of the piety (a strong respectful belief and strict observance of religious principles in everyday life) of the Muslims in the East by those in the West; and intolerable economic disparities (Mascarenhas, 1971) ${ }^{11}$. The first spark of all grievances was expressed in the language movement in 1952. Subsequent nationalist fervor was evinced through the victory of the Juctafront government in the 1954 elections. The West Pakistani political party failed miserably to win the support of the people of East Pakistan. The first success of this nationalist movement was the Pakistani Government's recognition of Bangla as a state language alongside Urdu in 1956 (Schendel, 2009). This was the first time the West Pakistani- dominated government had acceded to a demand of the East Pakistani nationalist movement. It was in these circumstances that the military dictator Ayub Khan took power as national leader in 1958. Khan was aware of the situation and from the very beginning of his presidency East Pakistan was given a greater share in central taxes than it had had in the period from 1947 to 1958 (Talbot, 1998). Khan also increased expenditure on public sector development. Despite this, he was cautious about the East Pakistani nationalist movement. This is clear in Ahmad's observation that "He would emphatically say that it was impossible for any country to subjugate East Pakistan. It was further speculated that infiltration was possible; but to subjugate the Province (the East) was impossible" (Ahmad, 1960, p. 16). The idea of commissioning the JSB suggested itself to him mainly as a way to appease the people of Bangladesh. It was an ostensibly decent gesture disguising a means of oppressing the freedom-loving people of East Pakistan. Schendel argues that "The military regime saw itself [Jatio Sangsad Bhaban] as stern, fair, constructive, efficient and avuncular. Most East Pakistanis, however saw it as autocratic, imperialist, violent and geared to perpetuating the vice-regal power of Ayub Khan" (Schendel, 2009 , p. 120,). Therefore it is evident that JSB originally came into being as an emblem of oppression.

\footnotetext{
10. Although it took another thirteen years after independence to complete the construction of Louis I Kahn's JSB, it was regarded even while still under construction as of similar significance to the Parthenon in the psyche of the Bangladeshi people since independence. Until the completion of JSB in 1983 all parliamentary sessions were held in a building developed as the provincial parliament during the period of united Pakistan and which now functions as the Prime Ministerial Secretariat's buliding. In the terms of this paper's argument and, as previously explained, because of Kahn's JSB's psychological presence in the heart of the people since independence, all parliamentary functions since the independence in 1971 will be viewed as being under the aegis of Kahn's Assembly Building.

11 The following figure clearly shows the economic disparities between East and West, for the period 1947-1955 (Lambert,1959, p.53)
}

West Pakistan (millions of Rs)

Financial assistance

Capital expenditure

Grants-in- aid

Educational grants

Foreign aid allocated

Defence expenditure

Foreign trade (exports)

Foreign trade (imports)

$$
\begin{aligned}
& 10,000 \\
& 2,100 \\
& 540 \\
& 1,530 \\
& 730 \\
& 4,650 \\
& 4,830
\end{aligned}
$$

6,220
East Pakistan (millions of Rs)

$$
\begin{gathered}
1,260 \\
620 \\
180 \\
240 \\
150 \\
100 \\
4,940 \\
2,580
\end{gathered}
$$


JSB: An Emblem of Emancipation: Through its emancipatory function as the venue where constitutional arrangements are made on behalf of the people and democratic values are expressed Jatio Sangsad Bhaban stands as the emblem of the hopes and aspirations of Bangladesh. Some outstanding emancipatory measures undertaken by lawmakers of JSB include the creation of the landmark constitution, the repeal of the Indemnity Bill, and the introduction of the national caretaker government. One of the most outstanding features of the Bangladeshi constitution was the unprecedented speed of its completion ${ }^{12}$. It took less than a year to complete, in contrast to the nine years occupied by the framing of former arch-rival Pakistan's constitution (Hakim, 2000). Bangladesh emerged as an independent nation on December 16, 1971; on November 4, 1972, only 325 days later, the parliament produced a fully-fledged constitution (Haq, 1973). The factors that helped speed up the process were (1), the nation's homogeneous character in language, culture, traditions and history; (2), the use of a single chamber legislature; (3), the preconceived notion of parliamentary democracy propagated in the six-point referendum by the Awame League before the 1970 elections; and (4), the country's unity under one political platform led by the Awame League. The absence of a strong opposition expedited the framing of the constitution (Hakim, 2000). The four fundamental tenets of the constitution are democracy, socialism, secularism, and Bengali nationalism. As noted above, this landmark constitution introduced a unicameral legislature, known as Jatio Sangsad (JS).The JS was to be elected through adult franchise. The members of JS elect the President, who is the Head of State (Hakim, 2000). One of the most important features of the constitution is its parliamentary form of government, similar to the British Westminister system (Hakim, 2000).

Another emancipatory act was the repeal of the Indemnity Bill of $1975 .{ }^{13}$ In November 1996, almost twenty years after the Indemnity Ordinance Bill had been promulgated; its repeal was unanimously passed (Hakim, 2000). At last, the killers of the father of the nation were brought to justice, and hanged on January 28, 2010. The parliamentarians of the JSB introduced a landmark system of neutral caretaker government which is unique in the world (Hakim, 2000). This transitional form of government is a non-party caretaker government (NCG) headed by a former Chief Justice in the role of chief advisor, along with some assisting advisors. The role of these officials is to administer the transition process from one government to next after an election in a free and impartial manner On March 19, 1996 the thirteenth constitutional amendment bill was introduced, proposing NCG for all ensuing parliamentary elections (Ahmed, 2003). The return to the parliamentary system in 1991 was a constitutional victory in the history of Bangladesh. After the introduction of the parliamentary system as a prerequisite of the 1972 constitution, the Awame League government had introduced a presidential form of government in 1974 through the fourth amendment of the constitution. In 1991, in the fifth JS, the parliamentary system was reintroduced and unanimously accepted to overwhelming acclamation ${ }^{14}$. This was regarded as the victory for the masses. Choudhury argues in this regard, "Thus

\footnotetext{
12 The initiative to formulate the constitution was taken on March 23, 1972, with the promulgation of the 'Bangladesh constituent assembly order' (p.o. no. 22). The membesr of this assembly were constituted mainly from the members of the Pakistan National Assembly and the East Pakistan Provincial Assembly from the elections of 1970 and 1971 (Haq, 1973). On April 10, 1972 a two-day session was convened comprising the 430-member Constituent Assembly. A 34-member constitution drafting committee was formed with Dr. Kamal Hossain, a renowned barrister and the Minister for Law and Parliamentary Affairs as its chairman. There was only one member of the opposition on the committee. About 74 drafting committee meetings took place. On October 12, 1972, after 300 hours of work, the Minister introduced the Constitution Bill into the assembly. There was a note of discontent from the Opposition political parties, who recognised that participation in the making of the constitution had lacked diversity and representation of all cross-sections of society. However they welcome the constitution and conceded that 'a bad constitution is better than no constitution'. A total of 163 amendments - 139 on the main body and 24 on the schedules and preamble - were proposed. The final draft of the constitution was presented on November 4,1972, and within less than two hours the constitution of the People's Republic of Bangladesh was collectively accepted without any objections. It is an exemplary instance of the acceptance of an important document like a constitution being accepted within such a short time (only 24 days) of being introduced (Haq, 1973). The constitution comprises 72 printed pages, with 153 articles divided into 11 parts and 4 appended schedules. It provided for supremacy of Sangsad, and came into force from December 16, 1972. General elections were called for March 7, 1973 (Haq, 1973).
}

${ }^{13}$ After Sheikh Mujibur Rahman, then President of Bangladesh and regarded as the father of the nation, was assassinated in 1975 by a small clique of disaffected army officers his successor Khondokar Mushtaq promulgated the Indemnity Ordinance, 1975, quarantining the killers from any punishment. This is regarded as a reprehensible act by most Bangladeshis, especially by the Awame League Party (Baxter, 1997).

14 The BNP election manifesto called for a presidential form of government. But BNP initiated the introduction of parliamentary government as a commitment to the joint declaration in the agitation against dictator Ershad. It was a rare instance of political concord (Hakim,2000) 
Bangladesh again bounced back and reintroduced parliamentary democracy in February 1991. The resilience and determination of ordinary people expressed through their political parties won a victory over the military regime with the installation of a caretaker government, which was unique to the political system of Bangladesh" (Choudhury, 2008, p.217).

The growing extent of democratic practice in Jatio Sangsad also resonates with the emancipatory function of the JSB. Ahmed argues that more recent parliaments should have done better in carrying out their responsibilities (Ahmed, 2003). The following chart clearly demonstrates the increasingly democratic nature of parliamentary practice, which ushered in an era of new hope ${ }^{1}$ (Ahmed, 2003, p.64,).

Nature of bill

\begin{tabular}{|c|c|c|c|}
\hline $\mathbf{J S}$ & new bill & ordinance turned bill & bill scrutinised by committees \\
\hline First & 35.7 & 53.3 & $2.0 \%$ \\
\hline Fifth & 21.0 & 34.7 & 4.0 \\
\hline Seventh & 28.4 & 2.6 & 100.0 \\
\hline
\end{tabular}

JSB: An Emblem of Repository of Danger: The JSB has experienced its share of negative, as opposed to emancipatory, practice. All such practices have revolved around partisan interests, confrontational politics, muscle power, corrupt parliamentarians, lack of strong oppositions in parliament, corrupt electioneering or electoral fraud, and oppressive laws. Partisan politics have been one of the dangerous elements that have evolved over the life of the assembly of the JSB It has been the general practice that the party in power uses unfair means to take control of every aspect of government, hindering the healthy functioning of Jatio Sangsad $^{1}$ (Ahmed, 2003, p.64). The most likely effect on opposition parties of such acts is to force them to boycott parliamentary functions, and sometimes to force resignations en masse $e^{15}$. In the absence of an opposition the parliament virtually becomes a dictatorial stage for treasury (Choudhury, 2008).Moreover it makes parliament dull and monotonous. Due to the lack of a quorum many important issues remain unresolved (Jahan, 2003). The party in power often feels no interest in bringing the opposition back into the parliament after such boycotts (Riaz, 2005). Even in the presence of both parties the parliament can turn into a battlefield, with acquisition for personal gain replacing any aspiration to enact emancipatory laws for the mass of the people. Both parties have sometimes preferred to play a reactive rather than a proactive role. Therefore inter-party conflict projects a depressing note into the landscape of Bangladesh Jatio Sangsad (Hakim, 2000). Ahmed claims that "Rather than contributing to the resolution of conflicts, the JS itself actually became the staging ground for bitter partisan struggle" (Ahmed, 2003, p.71).

Unfortunately the Assembly of the JSB has become a den of morally debauched individuals. Instead of nurturing democratic values and ideas in most parliamentary sessions the heart of Sangsad Bhaban has became a melting pot of rich thieves, thugs and criminals (Hussain, 2000). Ahmed points out that "The criminalization of politics poses a serious blow to the natural growth of representative institutions. Anyone with muscle and money can now hope to 'buy' a nomination with the major parties, and can even elected to the parliament" (Ahmed, 2003, p.73). Apart from abstaining from their respective functions, opposition parliamentarians encourage undue confrontational politics in the streets. Almost all oppositions in Jatio Sangsad have questioned the legitimacy of treasury, privileging a strategy of street violence and hartals. Hartal, or street politics, has become a stumbling block to the healthy progress of Assembly culture ${ }^{16}$ (Hakim,

\footnotetext{
15 All of the first four parliaments collapsed earlier than the normal tenure. Military intervention led to the suspension of the first two parliaments. The third and fourth succumbed to people's movements against their perceived illegitimacy (Hakim, 2000). One of the longest boycotts by the Opposition took place in 2003-2004: after eleven months, the opposition Awame League joined parliament in June 2004 and began to participate in the parliamentary standing committees of various ministries fourteen months after their inception (COMMENT: inception of what?) (Reaz, 2005)
}

16, 17 all first four parliaments collapsed earlier than the normal tenure. Military intervention led to suspension of first two parliaments. The third and fourth parliament succumbed to death due to people's movement against illegitimate parliament (Hakim, 2000). One of the longest boycott by the opposition took place in 2003-2004.After 11 month boycott, the opposition Awame league joined parliament in June 2004 and started activities in parliamentary standing committee on various ministries 14 months after their inception (Ali Reaz, 2005) 
2000). Rshiduzzaman argues, 'Hartal, a vehicle of opposition empowerment and the embodiment of Bangladesh politics, has polarized opinion and defied institutional norms and constitutional practices. No matter who was in power, no matter how fair was the poll, and no matter what form of constitution defined the authority, a determined opposition riding the crest of billowing Hartals could bring down a government." (Rashiduzzaman, 1997, p.255,).

Unfair electioneering processes also marred the sanctity of Jatio Sangsad in the first four parliaments ${ }^{17}$. A transparent and accountable electoral process is regarded as fundamental to the proper functioning of Jatio Sangsad. Hakim has described electoral malpractice in these terms: "The first JS elections held in 1973 witnessed the first though light display of electoral irregularities. In the second JS elections held in 1979 the degree of rigging was intensified, and the electoral process was simply reduced to a farce in the third and fourth JS elections held in 1986 and 1988 respectively. Stuffing the ballot boxes with false votes, massive violence in and around the polling centres, driving the genuine voters out of the polling centres by the government sponsored musclemen, and manipulation of election results by surreptitious counting became a part of the electoral game" (Hakim, 2000, p.101). One of the dangerous practices of parliaments in the JSB is the act of amending a well established constitution by political parties for their own benefit. From the introduction of the constitution until 2004 fourteen amendments have been carried out. Particularly controversial amendments have been the fourth, fifth and eighth. The fourth amendment altered the constitution from the Indian parliamentary type to the French presidential one, and introduced a one party system. The fifth removed secularism as one of the four basic principles of the constitution and included Koranic verse in the preamble. The eighth declared Islam to be the state religion (Khan, 1997)

The most notorious of all these amendments is the fourth. On January 25, 1975, an amendment to the constitution was adopted which proclaimed that "according to the amendment no legal action can be constituted in any court of law against the president. And no court can issue any warrant of arrest or detention order against the president. No citizen is allowed to form any political party or join in any political activities other than the national party. The president will also be the commander in chief of the armed forces" (Cited in Hussain, 2001, p 45). According to many observers this was regarded as a constitutional coup since it provided Sheikh Mujibur Rahman with absolute power to both structure his own party and suppress all others ${ }^{18}$ (Hussain, 2001). Apart from all these undemocratic constitutional amendments the Jatio Sangsad passed several other acts that cast a deep shadow over the spirit of democratic values. The most inimical of these was 'Special Power Act 1974', enacted by the Jatio Sangsad in February of that year under article 33 of the constitution (Choudhury, 2008). In relation to this law, Choudhury points out that "Individual liberty, and freedom of press and association, were all brought under the purview of this law. In its application it was found that the law was more used against the political dissidents than so-called anti social elements. Although adequate measures were taken to handle the offences, they were violated at every opportunity" (Choudhury, 2008, p.155).

One particularly ominous and shameful chapter that took place in the JSB was two parliamentary sessions during Dictator General Ershad's regime. The first of these was held on July 9, 1986. This was an illegitimate session under an illegitimate government ${ }^{19}$. It was paradoxical that such an undemocratic atmosphere should have reigned in an institution aspiring to be an emblem of democracy in the very first session after its construction. That architect Kahn's democratic icon was commissioned under the military dictator Ayub Khan

parliamentary standing committee on various ministries 14 months after their inception (Ali Reaz, 2005)

${ }^{18}$ Like the content of the bill, the bill's passage itself was dictatorial in nature. Contraryl to regular practice the bill was introduced immediately upon the arrival of all MP's into the chamber, without the mormal seven day's notice. Most of the treasury bench members were not aware of the content and severity of the Bill. Voting on the Bill was rushed through in three minutes and it was passed by a margin of 290-0.The whole process of constitutional amendment took thirty minutes. (Jamshed,2008, p.123)

\footnotetext{
${ }^{19}$ General Ershad took power after a bloodless coup in 1982. On March 24 he declared martial law and assumed supreme authority over Bangladesh. From April1 he allowed political activities to be conducted only under the strong supervision of the military backed regime. After a sham election in mid-October 1986, in the midst of boycotts and general strikes called by his opponents, Ershad emergedt victorious. After assuming office as an elected member, he initiated the process of legitimising his coup and subsequent actions. Thus the first session after the completion of architect Kahn's Jatio Sangsad Bhaban Complex in 1983 was a merely a political travesty (Baxter, 2008).
} 
in the period before independence and hosted its first session under another military dictator, General Ershad, in the first bloom of Bangladesh's independence, was a notable contradiction of its intended purpose $^{20}$. The attitudes and double standard of lawmakers pose a serious threat to the struggling democracy of Bangladesh and so to the image of Sangsad and the JSB. There have been instances of parliamentarians acting in contravention of their stated positions for their own benefit. Baxter elucidates one such incident. "The opposition found itself in an odd position. It had declared the parliament elected in February to be 'illegal', but this 'illegal' parliament had passed an act that conformed to the opposition's demands. An act passed by an 'illegal' Parliament became in the eyes of the opposition a legal action and the opposition prepared to contest the new election" (Baxter, 1997, p.126).

JSB: An Emblem of Opportunity: The JSB is regarded as the most iconic architectural masterpiece in Asia. Khalid Ashraf claims that "Louis I Kahn's capital Complex at Dhaka is an epic work. Next to Chandigarh it is the most important landmark to influence the architectural destiny of the region" (Ashraf, 1994). The JSB has immense potential to serve positive ends, as it is regarded as Kahn's most important work. It won the Aga Khan award for architectural excellence despite its huge construction and maintainance costs (Serageldin \& Hamed, 1990). It therefore offers immense scope, by capitalising on its architectural merit, to make Bangladesh's capital, Dhaka, a cultural icon able to inspire global admiration and reflect global aspirations. Drawing on the JSB's qualities Dhaka might become a city of world significance. Kong argues in relation to buildings of such symbolic and architectural significance as the JSB, "These often monumental structures are intended to support a vibrant cultural life, in order to attract and sustain global human and economic flows" (Kong, 2007, p. 382,). But he also notes that grand cultural icons are not the only prerequisites for endowing a city with global significance. Other issues like political stability, environmental practices and international relations are also vital to achieving the status of a global city (Kong, 2007).

Apart from its architectural excellence the JSB is regarded as a national emblem and the crucible for the spirit and idea of national identity (Choudhury, Armstrong 2012). It is the expression of the political dimension of national identity, incorporating the democratic values of the constitution (Choudhury \& Armstrong, 2012). The historian of architecture Ksiazek explains, "That the national assembly building was intended to embody democratic ideals is everywhere apparent in Kahn's statements about the project" (Ksiazek, 1993, p.428). This Parthenon of the East evokes a sense of pride in the hearts of the Bangladeshi people (Choudhury \& Armstrong, 2012). The JSB has therefore colossal potential to unify opposing elements within the country who are constantly engaged in discord and wrangling. Through its symbolic and iconic status in the world, it can fan a fresh glow of hope for the masses of Bangladesh and usher in new era for the developing nation.

\section{Results and Discussion}

The paper attempts to delineate new dimensions of the iconic Jatio Sangsad Bhaban through comprehensive analysis of its various aspects ranging, from its architectural form to its functioning as a platform for law makers. The process considers that these elements and qualities are expressions of the dual aspects of nationalism, a study of which can illuminate the highs and lows of this revered structure. The paper's significance is that it elevates the status of this iconic building from a mere aesthetic object to an object of multiple dimensions incorporating social, political and human issues. By linking the duality of nationalism and the duality of Bangladeshi nationalism with a symbolic building this paper sets a new direction for the scholarly interpretation of symbolic buildings like Jatio Sangsad Bhaban.

In Retrospect: The paper prompts thought about the duality of nationalism and captures the dual aspect of an apparent product of nationalism. Nationalism as a dual human construct of human and the JSB as the emblem of that duality are the keynotes of this paper. This duality of the JSB has been explored through the lens of Alter's theory of nationalism. The four components of nationalism - oppression, emancipation, danger and opportunity - have been interpreted through the dual character of this symbolic building by exploring its

\footnotetext{
${ }^{20} \mathrm{Kahn}$ envisioned that the democratic spirit embodied by his building might actually transcend its architectural merit. Anderson points out "Kahn's search was not primarily for physical, built institutions, but rather for what underlies or motivates these associations" (1995, p. 10).
} 
genesis, the constitutional issues played out in it, and its architectonics. Nationalism is a political and cultural construct. The constitutional issues discussed under the rubrics of danger and emancipation can be connected to the political aspect of the JSB. The discussion on opportunity revolving around the iconic and national identity of the JSB can be connected to the cultural construct of nationalism; both the cultural and political aspects of nationalism have been enunciated through the discussion of pertinent issues.

\section{Conclusion}

In conclusion it can be convincingly argued that despite the presence of duality in both its tangible (architectonics) and intangible (in-house constitutional practice) forms the JSB can still stand as a positive force in the life of Bangladesh. We would argue that the potential for opportunity is much the strongest. In terms of legislative function the JSB can emerge as the repository of healthy democratic practice. It has already travelled a long way along an anxiety-ridden path from its formative period to its present democratic status. It has succeeded in transiting from being monopolised by single party government to becoming a competitive multi-party institution (Ahmed, 2003). If legislators and politicians abandon the confrontational path of hartal and boycott and engage in dialogue on all issues of national importance the true essence of Louis I Kahn's JSB will be sure to bloom and flourish.

\section{References}

Ahmad, M. (1960). My Chief. Lahore, Pakistan: Longmans, Green.

Ahmed, N. (2003). From Monopoly to Competition: Party Politics in the Bangladesh Parliament (1973-2001). Pacific Affairs, 76(1), 55-77.

Anderson, S. (1995). Public Institutions: Louis I. Kahn's Reading of Volume Zero. Journal of Architectural Education, 49(1), 10-21.

Ashraf, K. K. (1994). Louis I. Kahn: National Capital of Bangladesh, Dhaka, Bangladesh, 1962-83. Global Architecture, 72, 1-47.

Alter, P. (1994). Nationalism. London: E. Arnold.

Anderson, B. R. O. G. (2006). Imagined communities: reflections on the origin and spread of nationalism. London; New York: Verso

Baxter, C. (1997). Bangladesh: From a Nation to a State. Boulder, Colo: West view Press.

Beiner, R. (1999). Theorizing Nationalism. Albany: State University of New York

Choudhury, B. \& Bell, G. (2011). The Engagement of Khan and Kahn in Jatio Sangsad Bhaban. Architecture plus Design, 28(4), 104-111

Choudhury, B. I. \& Armstrong, P. (2012). Monuments and Architecture Shaping Bangladeshi Identity. Global Built Environmental Review, 8(3), 45-67

Choudhury, J. (2008). Bangladesh-Failure of a Parliamentary Government. London: Jamshed Foundation.

Durkheim, E. (2005). The Dualism of Human Nature and its Social Conditions. Durkheimian Studies, 11(1), 3545.

Eriksen, T. H. (1991). Ethnicity versus Nationalism. Journal OF Peace Research, 28(3), 263-278.

File no W-CAP-58/ACE, Collection no -3 year 1966, Public Works Department, Bangladesh)

(File No-W-CAP-16(1) ACE, Collection No-X1 Year-1973-74, Public Works Department, Bangladesh)

Gellner, E. (1998). Nationalism. London: Phoenix.

Guibernau, M. M. (2007). The identity of nations. Cambridge: Polity.

Hakim, M. A. (2000). The Changing Forms of Government in Bsangladesh, Dhaka: Bangladesh Institute of Parliamentary Studies.

Haq, A. F. (1973). Constitution Making in Bangladesh. Pacific Affairs, 46(1), 59-76.

Hershberger, R. G. (1970). Architecture and Meaning. Journal of Aesthetic Education, 4(4), 37-55.

Hussain, S. M. (2001). Bangladesh 1975-1981 Transition from Autocracy to MultiParty Democracy: Dhaka, Meem Printers.

Hussain, A. (2000). Anatomy of Hartal Politics in Bangladesh. Asian Survey, 40(3), 508-529.

Hutchinson, J. A. D. S. (1994). Nationalism. Oxford: Oxford University Press.

Hutchinson, J. (1994). Cultural Nationalism and Moral Regeneration. Nationalism. J. H. A. D. Smith: Oxford, Oxford University Press.

Jahan, R. (2003). Bangladesh in 2002: Imperiled Democracy. Asian Survey, 43(1), 222-229. 
Kamenka, E. (1973). Nationalism. Sydney: Southwest Press Limited

Kellas, J. G. (1998). The Politics of Nationalism and Ethnicity. New York: St. Martin's Press.

Khan, Z. R. (1985). Islam and Bengali Nationalism. Asian Survey, 25(8), 834-851.

Khan, Z. R. (1997). Bangladesh's Experiments with Parliamentary Democracy. Asian Survey, 37(6), 575-589.

Kohn, H. C. J. C. (2008). The Idea of Nationalism: A study in its Origins and Background. New Jersey: The Mcmillan Company.

Kong, L. (2007). Cultural icons and Urban Development in Asia: Economic Imperitive, National Identity, and Global City Status. Political Geography, 26, 383-404.

Kramer, L. (1998). Nationalism Political Cultures in Europe and America, 1775-1865. New York: Twayne Publishers.

Ksiazek, S. W. (1993). Architectural Culture in the Fifties: Louis Kahn and the National Assembly Complex in Dhaka. The Journal of the Society of Architectural Historians, 52(4), 416-435.

Ksiazek, S. W. (1995). Changing Symbol in Public Life: Louis Kahn's Religious and Civic Projects 1944-1966 and Architectural Culture at the End of the Modern Movement. Unpublished PhD, New York, Department of Architecture and Planning, Colombia University.

Lambert, R. D. (1959). Factors in Bengali Regionalism. Far Eastern Survey, 28(4), 49-58.

Lowrie, S. G. (1930). Nationalism. International Journal of Ethics, 41(1), 35-49.

Madan, T. N. (1972). Two Faces of Bengali Ethnicity: Muslim Bengali or Bengali Muslim. The Developing Economies, 10(1), 74-85.

Mascarenhas, A. (1971). The Rape of Bangla Desh. Delhi: Vikas.

Miller, T. C. (1993). The Duality of Human Nature. Politics and the Life Sciences, 12(2), 221-241.

Mitra, P. K. (2007). The Dissent of Nazrul Islam. New Delhi: Oxford University Press.

Osmany, S. (1992). Bangladeshi Nationalism, History of Dialectics and Dimensions, Dhaka: UPL.

Özk*'*ml*, U. (2000). Theories of nationalism: a critical introduction. Basingstoke, Hampshire England; New York: Palgrave Macmillan.

Rashiduzzaman, M. (1997). Political Unrest and Democracy in Bangladesh. Asian Survey, 37(3), 254-268.

Riaz, A. (2005). Bangladesh in 2004: The Politics of Vengeance and the Erosion of Democracy. Asian Survey, 45(1), 112-118.

Serageldin, I. \& Hamed, S. E.D. (1990). A Modest and Delightful Balance. Landscape Architecture, 80(8), 49-51.

Sathyamurthy, T. V. (1983). Nationalism in the Contemporary World. New Jersy, Allanheld: Osman Publishers. Schendel, W. V. (2009). A History of Bangladesh. Cambridge, UK: Cambridge University Press

Schuman, H. (1972). A Note on the Rapid Rise of Mass Bengali Nationalism in East Pakistan. American Journal of Sociology, 78(2), 290-298.

Smith, A. D. (2006). Nationalism Cambridge: Polity Press

Tagore, R. (1991). Nationalism. London: Papermac.

Talbot, I. (1998). Pakistan: A Modern History. New York: Palgrave Macmillan.

Uddin, S. M. (2006). Constructing Bangladesh: religion, ethnicity, and language in an Islamic nation. Chapel Hill: University of North Carolina Press.

Vale, L. J. (2008). Architecture, Power, and National Identity. 2nd Ed. New Haven, CT: Yale University Press. 